\title{
Preparation, characterization, antimicrobial and cytotoxicity studies of copper/zinc- loaded montmorillonite
}

\author{
Lefei Jiao ${ }^{1}$, Fanghui Lin', Shuting Cao ${ }^{1}$, Chunchun Wang ${ }^{1}$, Huan $\mathrm{Wu}^{1}$, Miaoan Shu ${ }^{1 *}$ and Caihong $\mathrm{Hu}^{1,2^{*}}$
}

\begin{abstract}
Background: A series of modified montmorillonites (Mt) including zinc-loaded Mt (Zn-Mt), copper-loaded Mt (Cu-Mt), copper/zinc-loaded Mt with different Cu/Zn ratio (Cu/Zn-Mt-1, Cu/Zn-Mt-2, Cu/Zn-Mt-3) were prepared by an ion-exchange reaction, and characterized using $X$-ray diffraction (XRD), fourier transformed infrared spectroscopy (FTIR) and transmission electron microscopy (TEM). The specific surface areas, antimicrobial activity and cytotoxicity of the modified Mt were investigated.
\end{abstract}

Results: In the modified Mt, hydrated Cu ions and Zn ions were exchanged in the interlayer space of Mt and the particles were irregular shapes. The results showed that Cu/Zn-Mt enhanced antibacterial and antifungal activity compared with Zn-Mt and Cu-Mt possibly due to the synergistic effect between Cu and Zn. Among the Cu/Zn-Mt with different $\mathrm{Cu} / \mathrm{Zn}$ raitos, $\mathrm{Cu} / \mathrm{Zn}-\mathrm{Mt}$ with a $\mathrm{Cu} / \mathrm{Zn}$ ratio of 0.98 or 0.51 showed higher antimicrobial activity against gram-negative bacteria (Escherichia coli), gram-positive bacteria (Staphylococcus aureus), fungi (Candida albicans). Moreover, the antimicrobial activity of Cu/Zn-Mt was correlated with its specific surface area. Cytotoxicity studies on IPEC-J2 cell showed a slight cytotoxicity of Cu/Zn-Mt.

Conclusions: The current data provide clear evidence that in terms of its antimicrobial activity and relatively low toxicity, the Cu/Zn-Mt holds great promise for applications in animal husbandry.

Keywords: Antimicrobial reagent, Modified montmorillonites, Synergistic antimicrobial effect

\section{Background}

Recently, various inorganic antimicrobial materials have been developed and have attracted considerable interest in animal husbandry [1-3]. Among various antimicrobial metals,Copper $(\mathrm{Cu})$ and $\mathrm{Zinc}(\mathrm{Zn})$ are normally used in animal feed in concentrations in excess of the nutritional requirements of the animals and for prevention of diarrhea disease, and also as an alternative to in-feed antibiotics for growth promotion $[4,5]$. However, the strategy has been criticized because high level of $\mathrm{Zn}$ and $\mathrm{Cu}$ give rise to microbial drug resistance [6-8]. Enteral bacteria, both commensal and pathogenic, in farmed animals have been shown to develop resistance to trace elements $(\mathrm{Cu}$ and $\mathrm{Zn}$ ) and concomitant cross-resistance to antimicrobial

\footnotetext{
* Correspondence: shuma@zju.edu.cn; chhu@zju.edu.cn

${ }^{1}$ Animal Science College, Zhejiang University, Key Laboratory of Animal Feed and Nutrition of Zhejiang Province, No.866, Yuhangtang Road, Hangzhou 310058, People's Republic of China

Full list of author information is available at the end of the article
}

agents. Such bacteria may be transferred to other animals and human [7]. Moreover, large quantities of $\mathrm{Cu} / \mathrm{Zn}$ were excreted, which would pose an environmental problem [4]. Therefore, it is essential to find an alternative to reduce $\mathrm{Cu} / \mathrm{Zn}$ supplementation for sustaining animal production.

Special attention has been paid to metal ions loading inorganic carrier, which are superior in terms of safety, and long-term antibacterial effectiveness when compared with conventional metal [9-11]. As for inorganic carriers, the use of clay minerals as supports for synthesis of various inorganic antimicrobial materials has attracted considerable interest, owing to their nontoxic, environmentally friendly characteristic, and easy preparation [12-15]. It has been demonstrated that heavy metal (silver, $\mathrm{Cu}, \mathrm{Zn}$, and so on) exchanged clay minerals can serve as an antimicrobial reagent in vitro $[8,10,16]$. Until recently, $\mathrm{Cu}$ or $\mathrm{Zn}$ exchanged clay minerals has been added to the animal feed as an antibiotic 
alternative $[4,8,15]$, with the additive amount of $\mathrm{Cu}$ and $\mathrm{Zn}$ being quite lower than that in conventional animal diet. Moreover, a few researches have reported that loading two metal ions onto montmorillonite (Mt) displayed obvious synergistic antimicrobial effect in vitro [17-19]. However, there are no data loading $\mathrm{Zn}^{2+}$ and $\mathrm{Cu}^{2+}$ onto Mt so far. It has been reported that $\mathrm{Cu}-\mathrm{Mt}$ and $\mathrm{Zn}-\mathrm{Mt}$ displayed different antibacterial and antifungal activity [10]. Mt with different metal loading capacity had different physical and chemical properties [20-22]. So whether the $\mathrm{Cu} / \mathrm{Zn}$ - loaded $\mathrm{Mt}(\mathrm{Cu} / \mathrm{Zn}-\mathrm{Mt})$ with different $\mathrm{Cu} / \mathrm{Zn}$ ratios will affect the antibacterial and antifungal effect in vitro or not need to been explored.

Moreover, since the ultimate location of $\mathrm{Cu} / \mathrm{Zn}-\mathrm{Mt}$ is the intestinal tract of animals, it is necessary to test its cytotoxicity using an in vitro model for safety consideration. Recently, a cell line from jejunum epithelium isolated from a neonatal unsuckled piglet, small intestinal porcine epithelial cell line (IPEC-J2) was characterized and used as an in vitro model system for study [23]. This cell lines exhibited strong similarities to primary intestinal epithelial cells, and can be used as an appropriate model through the advantage of direct comparison with the experimental animals [24]. Therefore, IPEC-J2 was selected for the cytotoxicity studies of $\mathrm{Cu} / \mathrm{Zn}-\mathrm{Mt}$.

In the present work, a series of modified Mt including $\mathrm{Zn}-\mathrm{Mt}, \mathrm{Cu}-\mathrm{Mt}, \mathrm{Cu} / \mathrm{Zn}-\mathrm{Mt}$ with different $\mathrm{Cu} / \mathrm{Zn}$ ratio $(\mathrm{Cu} / \mathrm{Zn}-\mathrm{Mt}-1, \mathrm{Cu} / \mathrm{Zn}-\mathrm{Mt}-2, \mathrm{Cu} / \mathrm{Zn}-\mathrm{Mt}-3)$ were synthesized. Their synergistic antibacterial and antifungal effect in vitro were compared. Considering the application of $\mathrm{Cu} / \mathrm{Zn}-\mathrm{Mt}$ in animal husbandry, cytotoxicity assay was measured, too.

\section{Methods}

\section{Materials}

Mt was obtained from the Inner Mongolia Autonomous Region, China. The content of the purified Mt was 99.0\%. The cation exchange capacity (CEC) was 1.30 $\mathrm{mmol} / \mathrm{kg} \mathrm{Mt}$. $\mathrm{ZnSO}_{4} \cdot 7 \mathrm{H}_{2} \mathrm{O}$ and $\mathrm{CuSO}_{4} \cdot 5 \mathrm{H}_{2} \mathrm{O}$ were purchased from Sinopharm Chemical Reagent Co., Ltd., China. Gram-negative Escherichia coli (E. coli, ATCC 25922), gram-positive Staphylococcus aureus (S. aureus, ATCC 29213) and Candida albicans (C. albicans, ATCC 10231, fungi) were purchased from China Center of Industrial Culture Collection.

\section{Preparation of modified Mt}

The Mt (Cu-Mt, Zn-Mt, Cu/Zn-Mt-1, Cu/Zn-Mt-2, Cu/ $\mathrm{Zn}-\mathrm{Mt}-3)$ were prepared by an ion-exchange reaction. Ten grams of the Mt was mixed with $0.1 \mathrm{~L}$ of $0.2 \mathrm{~mol} / \mathrm{L}$ $\mathrm{NaCl}$ solution. The dispersion was agitated for $5 \mathrm{~h}$ on a magnetic stirrer (700 rpm). The Na-Mt was then separated by centrifugation $(15 \mathrm{~min}, 8000 \times \mathrm{g})$ and washed with deionized water for three times. The washed

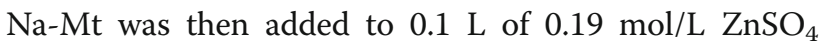
solutions, $0.2 \mathrm{~mol} / \mathrm{L} \mathrm{CuSO}_{4}$ solutions, $0.2 \mathrm{~mol} / \mathrm{L} \mathrm{CuSO}_{4}$ and $\mathrm{ZnSO}_{4}$ mixed solutions (the ratio of $\mathrm{Cu}$ and $\mathrm{Zn}$ is 1:1, 1:2, 1:4), respectively. The dispersion was agitated at $60{ }^{\circ} \mathrm{C}$ for $6 \mathrm{~h}$ on a magnetic stirrer to accelerate the cation exchange. After centrifugation, the sediment was washed with deionized water for three times, dried at $80{ }^{\circ} \mathrm{C}$ over night, and ground to a size less than 300 mesh. Zinc or/and copper concentration in the modified Mt were measured by atomic absorption spectroscopy (ICE 3300, Thermo Fisher Scientific, Waltham, USA). The $\mathrm{Cu}$ concentration of $\mathrm{Cu}-\mathrm{Mt}$ was $5.70 \%$. The $\mathrm{Zn}$ concentration of $\mathrm{Zn}-\mathrm{Mt}$ was $5.62 \%$. The $\mathrm{Cu}$ and $\mathrm{Zn}$ concentration of $\mathrm{Cu} / \mathrm{Zn}-\mathrm{Mt}-1$ were $2.78 \%, 2.85 \%$, respectively. The $\mathrm{Cu}$ and $\mathrm{Zn}$ concentration of $\mathrm{Cu} / \mathrm{Zn}-\mathrm{Mt}-$ 2 were $1.89 \%, 3.72 \%$, respectively. The $\mathrm{Cu}$ and $\mathrm{Zn}$ concentration of $\mathrm{Cu} / \mathrm{Zn}-\mathrm{Mt}-3$ were $1.15 \%, 4.45 \%$, respectively. .

\section{Characterization of the specimens}

A PANalytical X'pert PRO powder diffractometer equipped with a $\mathrm{Cu} \mathrm{K} \alpha$ radiation source was employed to determine the phase compositions and structures of the samples at $40 \mathrm{kV}$ and $30 \mathrm{~mA}$. Fourier transform infrared spectrometer (FTIR) was performed with a Nicolet Avatar 37- DTGS FT-IR spectrophotometer to study the structure of the materials by analyzing the vibrational frequencies of chemical bonds. Transmission electron microscopy (TEM) and energy-dispersive $\mathrm{x}$-ray spectroscopy (EDX) (Tecnai G2 F20 S-TWIN; FEI Company, Hillsboro, OR, USA) were carried to characterize the microstructure of the samples.

\section{Antimicrobial activity of the specimens}

For antimicrobial experiments, the minimum inhibitory concentrations (MIC) of the specimens were estimated by a two-fold diluting method. The typical microorganisms of E. coli, S. aureus and C. albicans were selected as indicators. Luria Bertani (LB) broth was used as a growing medium for E. coli and $S$. aureus. C. albicans was cultivated in liquid sabouraud medium. Bacterial strains were grown overnight and diluted with fresh medium to achieve an approximate density of $10^{7} \mathrm{CFU} / \mathrm{mL}$. Specimens of each material (Mt, $\mathrm{Cu}-\mathrm{Mt}, \mathrm{Zn}-\mathrm{Mt}$ and $\mathrm{Cu} / \mathrm{Zn}-\mathrm{Mt}$ ) were put into tubes containing $5 \mathrm{~mL}$ LB broth or liquid sabouraud medium, and then two-fold diluted into different concentrations. Bacterial inoculums were added to tubes with a final concentration of $10^{5}$ cells $/ \mathrm{mL}$. Each specimen was determined in triplicate. The bacteria-mineral mixtures were incubated at $37{ }^{\circ} \mathrm{C}$ for $24 \mathrm{~h}$, with continuous shaking at $200 \mathrm{rpm}$. The MIC of the specimens was determined by the lowest concentration of the specimens that inhibited completely the bacteria or fungi visible growth when judging by eye [25]. 
Particle size, specific surface areas and antimicrobial assays of $\mathrm{Cu} / \mathrm{Zn}-\mathrm{Mt}$

$\mathrm{Cu} / \mathrm{Zn}-\mathrm{Mt}$ was ground to a size less than 100, 200, 300, 400 mesh, respectively. The N2 adsorption isotherms and specific Brunauer-Emmitt-Teller (BET) surface areas of $\mathrm{Cu} / \mathrm{Zn}$-Mt were measured at $77 \mathrm{~K}$, using a Tristar 3000 specific surface area and porosimetry analyzer (Micromeritics Instrument Corp., USA). All the samples were degassed at $623 \mathrm{~K}$ for $1 \mathrm{~h}$ under vacuum before analysis.

For antimicrobial assays of $\mathrm{Cu} / \mathrm{Zn}-\mathrm{Mt}$ with different article size and specific surface areas, $\mathrm{Cu} / \mathrm{Zn}-\mathrm{Mt}$ was put into tubes containing nutrient broth to achieve a concentration of $400 \mathrm{mg} / \mathrm{L}$, and then the bacterial inoculums (E. coli or $S$. aureus or C. albicans) were added with an approximate density of $10^{5}$ cells $/ \mathrm{mL}$. The tubes without $\mathrm{Cu} / \mathrm{Zn}-\mathrm{Mt}$ served as the control group. After incubation at $37{ }^{\circ} \mathrm{C}$ for $24 \mathrm{~h}$, the mixtures were subjected to successive 10 -fold serial dilutions in the corresponding medium, mixed with a vortex shaker to ensure dispersion and quantitatively cultured in duplicate onto agar plates to determine the number of viable bacteria. The viable cell counts were expressed as fold changes, calculated relative to the control group.

\section{Cytotoxicity assay of $\mathrm{Cu} / \mathrm{Zn}-\mathrm{Mt}$}

Cytotoxicity of $\mathrm{Cu} / \mathrm{Zn}-\mathrm{Mt}$ was performed on IPEC-J2 cell by tetrazolium dye (MTT) based assay. Briefly, cells were seeded into 96-well culture plate in triplicate $(1.2 \times$ $10^{5}$ number of cells in $100 \mu \mathrm{L}$ DMEM). Mono-layers of cells were treated with $\mathrm{Cu} / \mathrm{Zn}-\mathrm{Mt}$ of increasing concentration $(0-0.5 \mathrm{mg} / \mathrm{mL})$. At the end of the culture period, $20 \mu \mathrm{L}$ of $5 \mathrm{mg} / \mathrm{mL}$ MTT stock solution was added in each well. After additional $4 \mathrm{~h}$ of incubation at $37{ }^{\circ} \mathrm{C}$, the resultant intracellular formazan crystals were solubilized with acidic isopropanol and the absorbance of the solution was measured at $570 \mathrm{~nm}$ using an ELISA reader (Emax, Molecular device, CA, USA).

\section{Results and Discussions}

Structure and morphology analysis of the specimens

XRD patterns were obtained to identify the intercalation of $\mathrm{Cu}^{2+}$ or and $\mathrm{Zn}^{2+}$ into Mt $[20,26]$. The measured interlayer spacings $d_{001}$ are shown in Fig. 1. Na-Mt displays a reflection at the $2 \theta$ value of $5.76^{\circ}$, which is assigned to $\mathrm{d}_{001}$ basal spacing of $1.534 \mathrm{~nm}$. As for modified Mt, the reflection was emerged at lower $2 \theta$ values of $5.34^{\circ}, 5.40^{\circ}, 5.36^{\circ}, 5.38^{\circ}, 5.37^{\circ}(\mathrm{Cu}-\mathrm{Mt}, \mathrm{Zn}-\mathrm{Mt}$, $\mathrm{Cu} / \mathrm{Zn}-\mathrm{Mt}-1, \mathrm{Cu} / \mathrm{Zn}-\mathrm{Mt}-2, \mathrm{Cu} / \mathrm{Zn}-\mathrm{Mt}-3)$, corresponding to the increased $\mathrm{d}_{001}$ basal spacing of $1.654 \mathrm{~nm}$, $1.638 \mathrm{~nm}, 1.649 \mathrm{~nm}, 1.641 \mathrm{~nm}, 1.645 \mathrm{~nm}$. It can be presumed that these increases after $\mathrm{Cu}^{2+}$ or/and $\mathrm{Zn}^{2+}$ ion exchange are caused by a difference in the size of hydrated form between $\mathrm{Cu}^{2+} / \mathrm{Zn}^{2+}$ and $\mathrm{Na}^{+}$ion, although

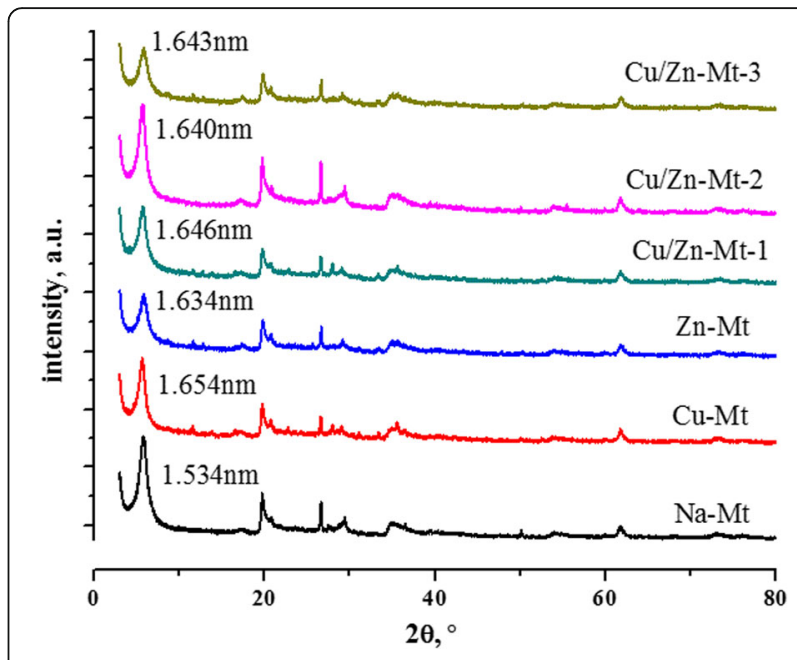

Fig. 1 XRD patterns of modified Mt

ion radius of $\mathrm{Cu}$ and $\mathrm{Zn}(0.072 \mathrm{~nm}, 0.074 \mathrm{~nm}$, respectively) is smaller than that of sodium $(0.095 \mathrm{~nm})$. The sodium ions in $\mathrm{Na}-\mathrm{Mt}$ have been exchanged with $\left[\mathrm{Zn}\left(\mathrm{H}_{2} \mathrm{O}\right)_{6}\right]^{2+}$ or/and $\left[\mathrm{Cu}\left(\mathrm{H}_{2} \mathrm{O}\right)_{6}\right]^{2+}[27]$. Moreover, no difference of $\mathrm{d}_{001}$ basal spacing was observed in modified Mt, which might be associated with similar ion radius between $\mathrm{Cu}^{2+}$ and $\mathrm{Zn}^{2+}$.

The infrared spectra of the specimens were obtained by the $\mathrm{KBr}$ method using an FTIR spectrometer and demonstrated in Fig. 2. Characteristic bands for Na-Mt are present around $3,405 \mathrm{~cm}^{-1}$ and $1,633 \mathrm{~cm}^{-1}(\mathrm{O}-\mathrm{H}$ stretching), $1,035 \mathrm{~cm}^{-1}$ (Si-O stretching), $529 \mathrm{~cm}^{-1}$ and $464 \mathrm{~cm}^{-1}$ (Si-O bending vibration) $[28,29]$. As for modified $\mathrm{Mt}(\mathrm{Cu}-\mathrm{Mt}$, $\mathrm{Zn}-\mathrm{Mt}, \mathrm{Cu} / \mathrm{Zn}-\mathrm{Mt})$, the $\mathrm{O}-\mathrm{H}$ stretching vibration band increased slightly, which can be attributed to the hydrated $\mathrm{Cu}^{2+} / \mathrm{Zn}^{2+}$ ions [26]. In addition, the positions of the $\mathrm{Si}-\mathrm{O}$ bending vibrations remained basically unchanged at $518 \mathrm{~cm}^{-1}(\mathrm{Si}-\mathrm{O}-\mathrm{Al})$ and $466 \mathrm{~cm}^{-1}$

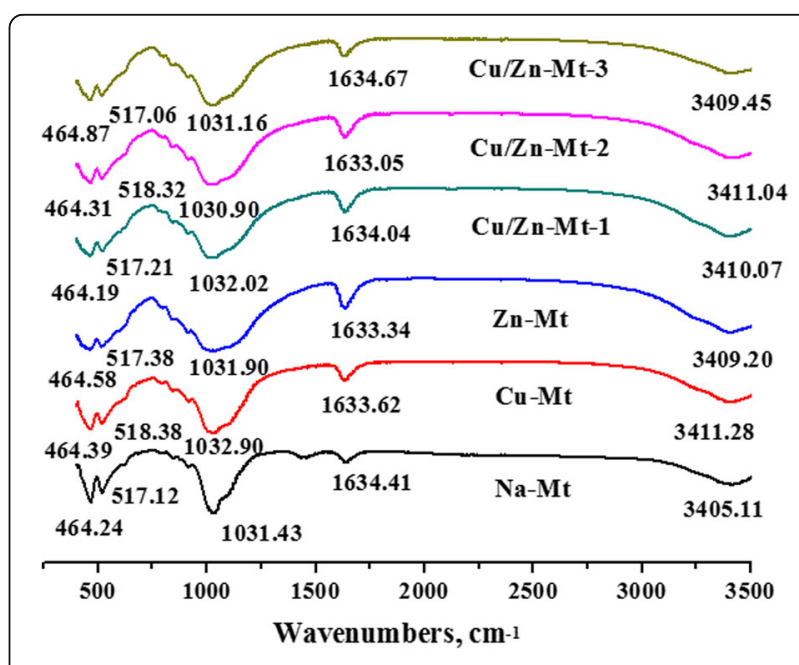

Fig. 2 FT-IR spectra of modified Mt 
a

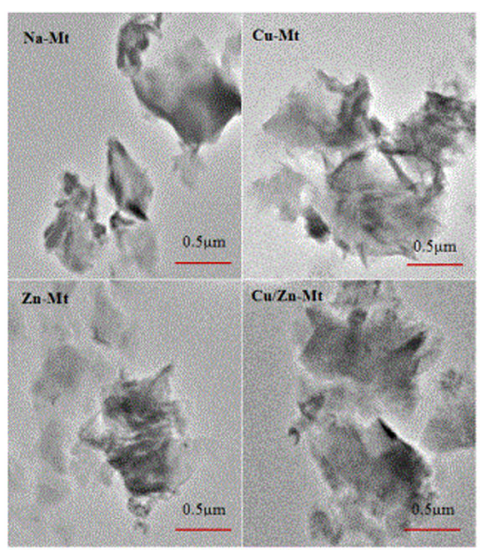

b
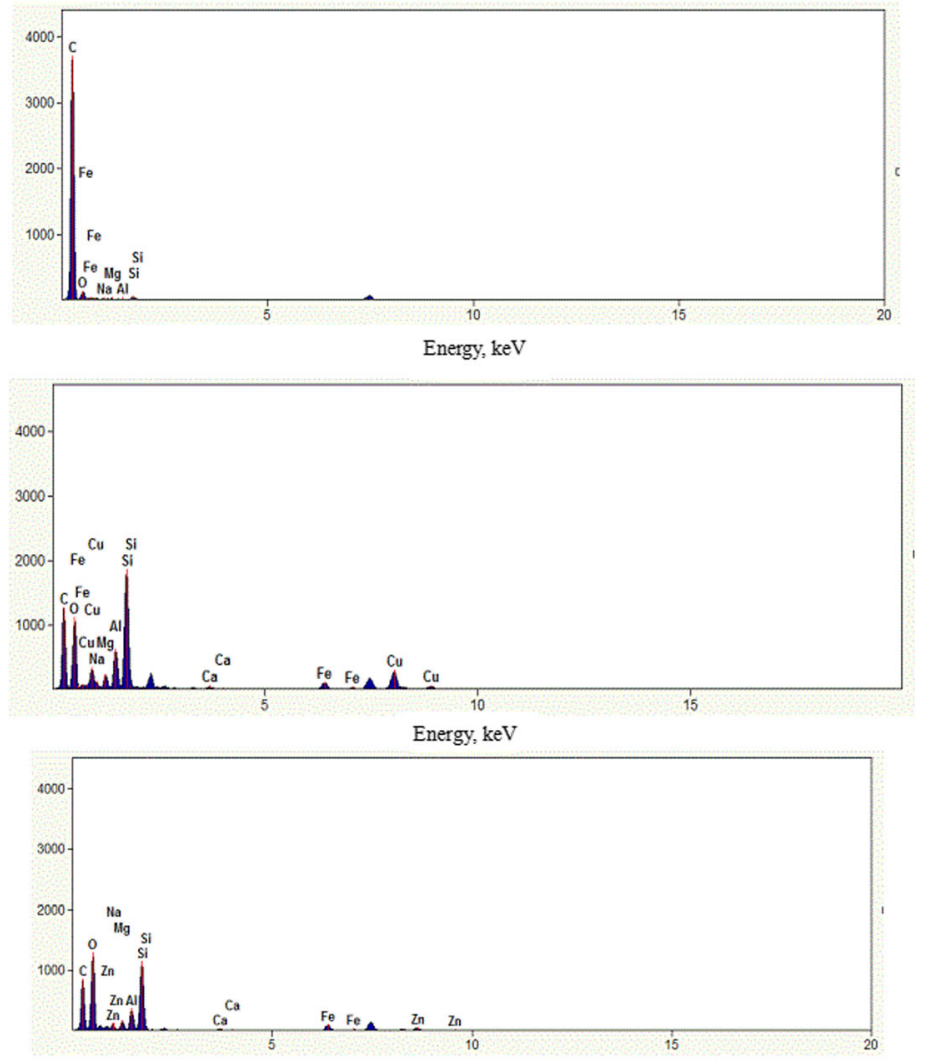

Energy, $\mathrm{keV}$

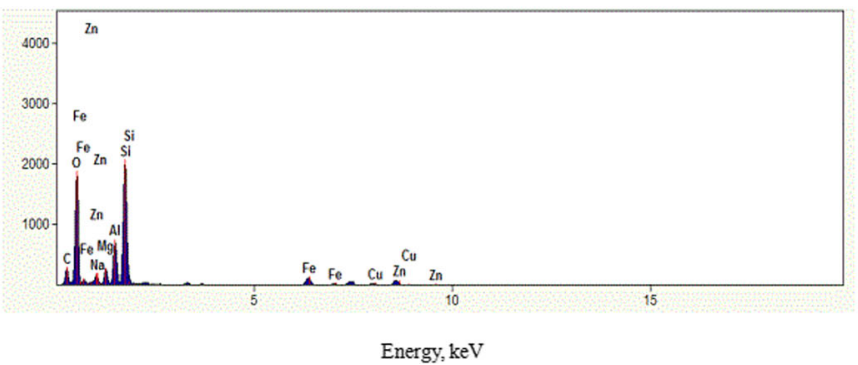

Fig. 3 TEM and EDX spectrum of modified Mt 
(Si-O-Si) for the $\mathrm{Cu} / \mathrm{Zn}-\mathrm{Mt}$, which indicated that the presence of $\mathrm{Zn}$ and $\mathrm{Cu}$ in the hexagonal cavities didn't affects this vibration in the experiment.

The TEM images reveal the internal structures of the Mt and modified Mt as presented in Fig. 3a. It was observed that the layered crystallites of Mt and modified Mt aggregated in large sized particles. Consistent with XRD, FTIR results, $\mathrm{Cu}$ or $\mathrm{Zn}$ loaded on the interlayers of Mt did not change the Mt's layered structure. Moreover, Fig. 3b shows the EDX spectrum of the specimens, confirming the presence of $\mathrm{Cu}$ or $\mathrm{Zn}$ in modified Mt. Apart from elements of $\mathrm{Na}-\mathrm{Mt}(\mathrm{Al}, \mathrm{Si}, \mathrm{O}, \mathrm{C}, \mathrm{Fe}, \mathrm{Mg}$ and $\mathrm{Na}$ ), peak of $\mathrm{Cu}$ or/and $\mathrm{Zn}$ was visible in $\mathrm{Cu}-\mathrm{Mt}, \mathrm{Zn}-$ $\mathrm{Mt}$ and $\mathrm{Cu} / \mathrm{Zn}-\mathrm{Mt}$. Peak of sodium is detected which indicates incomplete exchange with $\mathrm{Cu}$ or/and $\mathrm{Zn}$.

\section{Antimicrobial assay of the specimens}

The antimicrobial activity of the specimens was investigated in Table 1 . In the case of Na-Mt, no antimicrobial activity was detected against the microorganisms (the MIC against the three kinds of microorganisms were all more than $10,000 \mathrm{mg} / \mathrm{L}$ ). Similar results have also been reported that Mt with large specific surface area could adhere to bacteria by electrostatic forces, but showed no bacteriostatic activity $[16,30]$. Moreover, results showed E. coli was more sensitive to modified Mt compared with $S$. aureus and C. albicans. One of the possible explanations of that difference in sensitivity is the different characteristics of the cell surfaces. It has been reported that the negative charge on the cell surface of gram-negative bacteria was higher than on gram-positive bacteria $[12,31]$. Due to a higher negative charge on cell surface, the interaction between E. coli and Mt (positively charged in the interlayer) was definitely stronger than that of S. aureus and C. albicans, which could facilitate contact of $\mathrm{Cu}^{2+}$ and $\mathrm{Zn}^{2+}$ with bacterial cells wall and thus enable their damaging effect to the bacteria.

In addition, the antimicrobial effect was detected in $\mathrm{Zn}-\mathrm{Mt}, \mathrm{Cu}-\mathrm{Mt}$ and $\mathrm{Cu} / \mathrm{Zn}-\mathrm{Mt}$ treatments. Compared with $\mathrm{Zn}-\mathrm{Mt}, \mathrm{Cu}-\mathrm{Mt}$ displayed higher antibacterial and antifungal activity, which was corresponded to the previous results $[10,12]$. The antibacterial and antifungal

Table 1 The antimicrobial activity of modified Mt

\begin{tabular}{|c|c|c|c|}
\hline \multirow[t]{2}{*}{ Sample } & \multicolumn{3}{|c|}{ MIC, mg/L } \\
\hline & E. coli & S. aureus & C. albicans \\
\hline $\mathrm{Na}-\mathrm{Mt}$ & $>10,000$ & $>10,000$ & $>10,000$ \\
\hline Cu-Mt & 411.63 & 657.78 & $1,315.56$ \\
\hline Zn-Mt & 823.26 & $1,315.56$ & 2631.12 \\
\hline Cu/Zn-Mt-1 & 328.89 & 411.63 & 823.26 \\
\hline Cu/Zn-Mt-2 & 328.89 & 411.63 & 823.26 \\
\hline Cu/Zn-Mt-3 & 411.63 & 657.78 & $1,315.56$ \\
\hline
\end{tabular}

properties of $\mathrm{Zn}-\mathrm{Mt}$ or $\mathrm{Cu}-\mathrm{Mt}$ could been attributed to the attraction, by electrostatic forces, of the negatively charged membrane of the bacteria to the surface of the $\mathrm{Mt}$, where the positive charged $\mathrm{Cu}$ or $\mathrm{Zn}$ ions kills the bacteria or renders them unable to replicate [20,32]. In the case of $\mathrm{Cu} / \mathrm{Zn}-\mathrm{Mt}$, the antibacterial and antifungal activity has been improved compared with $\mathrm{Cu}-\mathrm{Mt}$ and $\mathrm{Zn}-\mathrm{Mt}$. $\mathrm{Cu} / \mathrm{Zn}-\mathrm{Mt}$ showed obvious synergistic antimicrobial effect. Similar to our findings, it was reported that compared with Chitosan/Ag and $\mathrm{CS} / \mathrm{ZnO}$, Chito$\mathrm{san} / \mathrm{Ag} / \mathrm{ZnO}$ composite displayed excellent antimicrobial activities against B. subtilis, E. coli, S. aureus, Penicillium, Aspergillus, Rhizopus and yeast [33]. Moreover, it was found that $\mathrm{Zn}^{2+}-\mathrm{Ce}^{3+}$ loaded Mt presented much higher antibacterial and antifungal efficiency than $\mathrm{Zn}^{2+}$ loaded $\mathrm{Mt}$ and $\mathrm{Ce}^{3+}$ loaded Mt [17]. A recent review indicated that different metals caused discrete and distinct types of injuries to microbial cells as a result of oxidative stress, protein dysfunction or membrane damage [34]. It has been reported that toxicity associated with $\mathrm{Cu}$ might be due to impaired membrane function and reactive oxygen species (ROS) mediated cellular damage [35]. Zn could initiate bacteriostasis though oxidation of cellular thiols or damaging $\mathrm{Fe}-\mathrm{S}$-containing dehydratases in vitro independently of ROS and inhibit these enzymes activity [36]. Therefore, we speculated that different antimicrobial mechanism might result in more effective damage to bacteria, which might require further study. What is more, the antibacterial and antifungal properties of $\mathrm{Cu} / \mathrm{Zn}$-Mts varied with different $\mathrm{Cu} / \mathrm{Zn}$ atomic ratios. Compared with $\mathrm{Cu} / \mathrm{Zn}-\mathrm{Mt}-3, \mathrm{Cu} / \mathrm{Zn}-\mathrm{Mt}-1$ and $\mathrm{Cu} / \mathrm{Zn}$ Mt-2 showed higher antibacterial and antifungal activity. So the study was especially focused on the structure and properties of $\mathrm{Cu} / \mathrm{Zn}-\mathrm{Mt}-2$ in the following research.

\section{Particle size, surface properties and antimicrobial activity of the $\mathrm{Cu} / \mathrm{Zn}-\mathrm{Mt}-\mathbf{2}$}

The effect of particle size on the antimicrobial activity of $\mathrm{Cu} / \mathrm{Zn}-\mathrm{Mt}(\mathrm{Cu} / \mathrm{Zn}-\mathrm{Mt}-2)$ was seen in Fig. 4. The antimicrobial activity increased with the enhancement of the specific surface area when the particle size decreased, which suggested that the overall antimicrobial effect is not only related to the presence and quantity of metal ions but also is affected by the surface characteristics of the modified Mt [16]. It was reasonable to state that the binding of $\mathrm{Cu} / \mathrm{Zn}-\mathrm{Mt}$ particles to the bacteria depended on the surface area available for interaction. Smaller particles having the larger surface area available for interaction would give higher antimicrobial effect than the larger particles [35].

\section{Cytotoxicity assay of the $\mathrm{Cu} / \mathrm{Zn}-\mathrm{Mt}-2$}

In order to utilize the antimicrobial effect of $\mathrm{Cu} / \mathrm{Zn}-\mathrm{Mt}$ for therapeutic purposes, it is absolutely essential to 

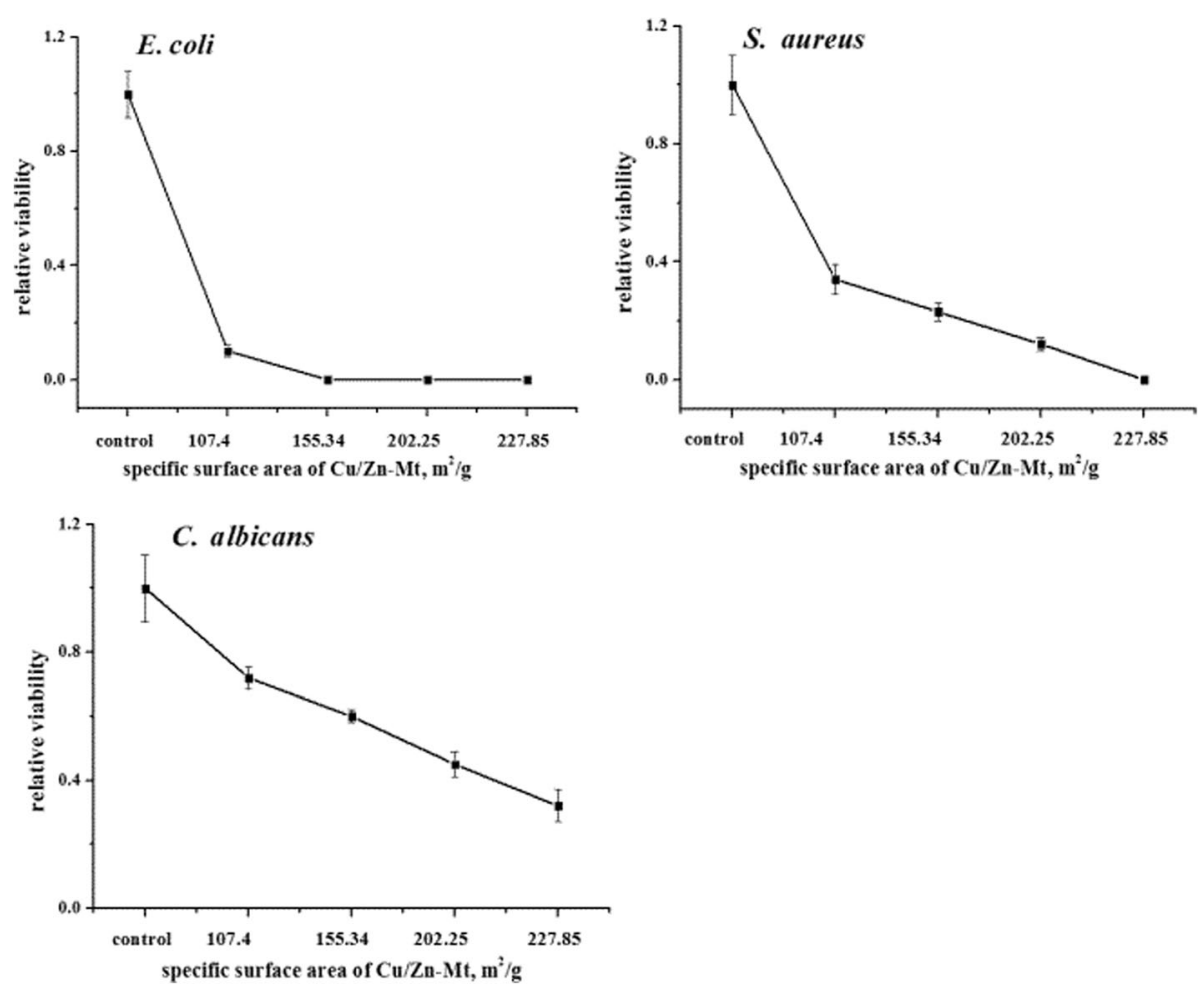

Fig. 4 The antimicrobial activity of Cu/Zn-Mt-2 with different specific surface area

perform a cytotoxicity study (Fig. 5). Cu/Zn-Mt-2 $(0.1 \mathrm{mg} / \mathrm{mL})$ exhibited a slight cytotoxicity $(\sim 10 \%)$ to IPEC-J2 cell within $24 \mathrm{~h}$ incubation by MTT assays. $\mathrm{Cu} /$ Zn-Mt-2 of higher concentration $(0.3 \mathrm{mg} / \mathrm{mL})$ led to increased cytotoxicity ( $20 \%)$ within $24 \mathrm{~h}$. Overall, the concentrations of the cell population showed stabilization at concentrations beyond the MIC value. This may be explained as follows, lower concentration of $\mathrm{Cu}$ or $\mathrm{Zn}$ had minimal adverse effect on cells in vitro [32,37]. Moreover, Mt has been regarded as a dermatological and

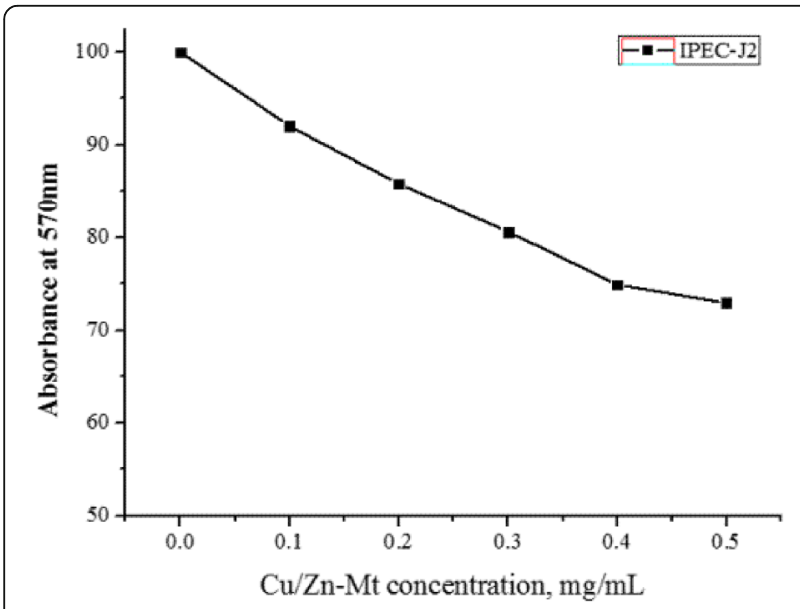

Fig. 5 The cytotoxicity of Cu/Zn-Mt-2 gastrointestinal protector by attaching to the cells and absorbing any toxic molecules due to their high absorptive capacity, which played an important role in reducing toxicity of $\mathrm{Cu} / \mathrm{Zn}-\mathrm{Mt}-2$ [38]. Therefore, $\mathrm{Cu} / \mathrm{Zn}-\mathrm{Mt}$ was good inorganic antimicrobial materials with slight cytotoxicity.

\section{Conclusion}

$\mathrm{Cu} / \mathrm{Zn}$-Mt with different $\mathrm{Cu} / \mathrm{Zn}$ ratios could be prepared by an ion-exchange reaction and showed synergistic antimicrobial effect and relatively low cell toxicity. Moreover, the antimicrobial activity of $\mathrm{Cu} / \mathrm{Zn}-\mathrm{Mt}$ was correlated with its specific surface area and $\mathrm{Cu} / \mathrm{Zn}$ ratios. Therefore, $\mathrm{Cu} / \mathrm{Zn}$-Mt holds great promise for applications in animal husbandry.

\section{Abbreviations}

Cu/Zn-Mt: Copper/zinc loaded montmorillonite; Cu-Mt: Copper loaded montmorillonite; Mt: Montmorillonite; Zn-Mt: Zinc loaded montmorillonite

\section{Acknowledgements}

Not applicable.

\section{Funding}

This work was jointly supported by the Special Fund for Agro-scientific Research in the Public Interest (No. 201403047), Science Technology Department of Zhejiang Province (2015C02022). The funders had no role in study design, data collection and analysis, decision to publish, or preparation of the manuscript.

Availability of data and materials

The datasets supporting the conclusions of this article are included within the article. 


\section{Authors' contributions}

LFJ conceived and designed the experimental plan. FHL and STC collected the experiments data. CCW and HW analyzed the data. LFJ wrote the paper $\mathrm{CHH}$ and MAS had primary responsibility for the final content. All authors read and approved the final manuscript.

\section{Competing interests}

The authors declare that they have no competing interests.

\section{Consent for publication}

Not applicable.

\section{Ethics approval and consent to participate} Not applicable.

\section{Author details}

'Animal Science College, Zhejiang University, Key Laboratory of Animal Feed and Nutrition of Zhejiang Province, No.866, Yuhangtang Road, Hangzhou 310058, People's Republic of China. ${ }^{2}$ Key Laboratory of Animal Nutrition and Feed in East China, Ministry of Agriculture, No.866, Yuhangtang Road, Hangzhou 310058, People's Republic of China.

Received: 15 November 2016 Accepted: 25 February 2017 Published online: 21 March 2017

\section{References}

1. Davis ME, Parrott T, Brown DC, de Rodas BZ, Johnson ZB, Maxwell CV, et al. Effect of a Bacillus-based direct-fed microbial feed supplement on growth performance and pen cleaning characteristics of growing-finishing pigs. J Anim Sci. 2008;86:1-7.

2. $\mathrm{Hu} C H, X i a \mathrm{MS}$. Adsorption and antibacterial effect of copper-exchanged montmorillonite on Escherichia coli K-88. Appl Clay Sci. 2006;b31:180-4.

3. Saavedra MJ, Dias CSP, Martinez-Murcia A, Bennett RN, Aires A, Rosa EAS Antibacterial effects of glucosinolate-derived hydrolysis products against Enterobacteriaceae and Enterococci isolated from pig ileum segments. Foodborne Pathog Dis. 2012:9:338-45.

4. Song J, Li YL, Hu CH. Effects of copper-exchanged montmorillonite, as alternative to antibiotic, on diarrhea, intestinal permeability and proinflammatory cytokine of weanling pigs. Appl Clay Sci. 2013;77-78:52-5.

5. Huang YL, Ashwell MS, Fry RS, Lloyd KE, Flowers WL, Spears JW. Effect of dietary copper amount and source on copper metabolism and oxidative stress of weanling pigs in short-term feeding. J Anim Sci. 2015;93:2948-55.

6. Jondreville C, Revy PS, Dourmad JY. Dietary means to better control the environmental impact of copper and zinc by pigs from weaning to slaughter. Livest Prod Sci. 2003:84:147-56.

7. Yazdankhah S, Rudi K, Bernhoft A. Zinc and copper in animal feed development of resistance and co-resistance to antimicrobial agents in bacteria of animal origin. Microb Ecol Health Dis. 2014;25:1-7.

8. Jiao LF, Ke YL, Xiao K, Song ZH, Lu JJ, Hu CH. Effects of zinc-exchanged montmorillonite with different zinc loading capacities on growth performance, intestinal microbiota, morphology and permeability in weaned piglets. Appl Clay Sci. 2015;112:40-3.

9. Zhao DF, Zhou J, Liu N. Preparation and characterization of Mingguang palygorskite supported with silver and copper for antibacterial behavior. Appl Clay Sci. 2006;33:161-70

10. Malachova K, Praus P, Rybkova Z, Kozak O. Antibacterial and antifungal activities of silver, copper and zinc montmorillonites. Appl Clay Sci. 2011;53:642-5.

11. Krishnani KK, Zhang Y, Xiong L, Yan YS, Boopathy R, Mulchandani A. Bactericidal and ammonia removal activity of silver ion-exchanged zeolite. Bioresource Techn. 2012;117:86-91.

12. Stanic V, Dimitrijevic S, Antic-Stankovic J, Mitric M, Jokic B, Plecas IB, et al. Synthesis, characterization and antimicrobial activity of copper and zincdoped hydroxyapatite nanopowders. Appl Surf Sci. 2010;256:6083-9.

13. Cai X, Zhang J, Ouyang Y, Ma D, Tan SZ, Peng YL. Bacteria-adsorbed palygorskite stabilizes the quaternary phosphonium salt with specifictargeting capability, long-term antibacterial activity, and lower cytotoxicity. Langmuir. 2013;29:5279-85.

14. Gaskell EE, Hamilton AR. Antimicrobial clay-based materials for wound care. Future Med Chem. 2014;6:641-55.
15. Wang $L C$, Zhang $T T$, Wen $C$, Jiang $Z Y$, Wang $T$, Wang $T$, et al. Protective effects of zinc-bearing clinoptilolite on broilers challenged with Salmonella pullorum. Poult Sci. 2012;91:1838-45.

16. Magana SM, Quintana P, Aguilar DH, Toledo JA, Angeles-Chavez C, Cortes $M A$, et al. Antibacterial activity of montmorillonites modified with silver. J Mol Catal a-Chem. 2008;281:192-9.

17. Tan SZ, Zhang KH, Zhang LL, Xie YS, Liu YL. Preparation and characterization of the antibacterial $\mathrm{Zn}(2+)$ or/and $\mathrm{Ce}(3+)$ loaded montmorillonites. Chinese J Chem. 2008;26:865-9.

18. Ramesh A, Hasegawa H, Maki T, Ueda K. Adsorption of inorganic and organic arsenic from aqueous solutions by polymeric Al/Fe modified montmorillonite. Sep Purif Technol. 2007;56:90-100.

19. Cai X, Dai GJ, Tan SZ, Ouyang Y, Ouyang YS, Shi QS. Synergistic antibacterial zinc ions and cerium ions loaded alpha-zirconium phosphate. Mater Lett. 2012:67:199-201.

20. Shi QS, Tan SZ, Yang QH, Jiao ZP, Ouyang YS, Chen YB. Preparation and characterization of antibacterial $\mathrm{Zn}^{2+}$-exchanged montmorillonites. J Wuhan Univ Technol. 2012;25:725-9.

21. Dahn R, Baeyens B, Bradbury MH. Investigation of the different binding edge sites for Zn on montmorillonite using P-EXAFS - The strong/weak site concept in the 2SPNE SC/CE sorption model. Geochim Cosmochim Ac. 2011:75:5154-68.

22. Churakov SV, Dahn R. Zinc adsorption on clays inferred from atomistic simulations and EXAFS spectroscopy. Environ Sci Technol. 2012;46:5713-9.

23. Geens MM, Niewold TA. Optimizing culture conditions of a porcine epithelial cell line IPEC-J2 through a histological and physiological characterization. Cytotechnology. 2011;63:415-23.

24. Schierack P, Nordhoff M, Pollmann M, Weyrauch KD, Amasheh S, Lodemann U, et al. Characterization of a porcine intestinal epithelial cell line for in vitro studies of microbial pathogenesis in swine. Histochem Cell Biol. 2006;125:293-305.

25. Xu GN, Qiao XL, Qiu XL, Chen JG. Preparation and characterization of nanosilver loaded montmorillonite with strong antibacterial activity and slow release property. J Mater Sci Technol. 2011;27:685-90.

26. Tanaka M, Itadani A, Abe T, Taguchi H, Nagao M. Observation of characteristic IR band assignable to dimerized copper ions in montmorillonite. J Colloid Interface Sci. 2007:308:285-8.

27. Kozák O, Praus P, Machovič V, Klika Z. Adsorption of zinc and copper ions on natural and ethylenediamine modified montmorillonite. Ceram-Silikaty. 2010;54:78-84

28. Darder M, Colilla M, Ruiz-Hitzky E. Biopolymer-clay nanocomposites based on chitosan intercalated in montmorillonite. Chem Mater. 2003:15:3774-80.

29. Tyagi B, Chudasama CD, Jasra RV. Determination of structural modification in acid activated montmorillonite clay by FT-IR spectroscopy. Spectrochim Acta A. 2006;64:273-8

30. Malachova K, Praus P, Pavlickova Z, Turicova M. Activity of antibacterial compounds immobilised on montmorillonite. Appl Clay Sci. 2009;43:364-8.

31. Du WL, Niu SS, Xu YL, Xu ZR, Fan CL. Antibacterial activity of chitosan tripolyphosphate nanoparticles loaded with various metal ions. Carbohydr Polym. 2009:75:385-9.

32. Bagchi B, Kar S, Dey SK, Bhandary S, Roy D, Mukhopadhyayc TK, et al. In situ synthesis and antibacterial activity of copper nanoparticle loaded natural montmorillonite clay based on contact inhibition and ion release. Colloid Surface B. 2013;108:358-65.

33. Li LH, Deng JC, Deng HR, Liu ZL, Li XL. Preparation, characterization and antimicrobial activities of chitosan/Ag/ZnO blend films. Chem Eng J. 2010; 160:378-82.

34. Lemire JA, Harrison JJ, Turner RJ. Antimicrobial activity of metals: mechanisms, molecular targets and applications. Nat Rev Microbiol. 2013:11:371-84.

35. Hong R, Kang TY, Michels CA, Gadura N. Membrane lipid peroxidation in copper alloy-mediated contact killing of Escherichia coli. Appl Environ Microbiol. 2012;78:1776-84.

36. Xu FF, Imlay JA. Silver(I), mercury(II), cadmium(II), and zinc(II) target exposed enzymic iron-sulfur clusters when they toxify. Escherichia coli. 2012;10:3614-21.

37. Lodemann U, Einspanier R, Scharfen F, Martens H, Bondzio A. Effects of zinc on epithelial barrier properties and viability in a human and a porcine intestinal cell culture model. Toxicol In Vitro. 2013;27:834-43.

38. Williams $L B$, Haydel SE. Evaluation of the medicinal use of clay minerals as antibacterial agents. Int Geol Rev. 2010;52:745-70. 